Links, J., Rombouts, J. E. \& KeULEN, P. (1957). J. gen. Microbiol. 17, 596-601

\title{
The 'Bulging Factor', a Fungistatic Antibiotic Produced by a Streptomyces Strain, with Evidence of an Active Water-excreting Mechanism in Fungi
}

\author{
By J. LINKS, J. E. ROMBOUTS and PITRIKA KEULEN \\ N.V. Philips-Roxane, Central Laboratory, Weesp, and Agrobiological \\ Laboratory, 's-Graveland, The Netherlands
}

SUMMARY: The 'bulging factor', a new antibiotic with a chemical nature related to streptothricin, is produced by a Streptomyces strain and was isolated as reineckate and picrate. A study on its mode of action resulted in the development of a plate technique for assaying bulging factor activity. Evidence is presented in support of a theory about the existence of an active water-excreting mechanism in fungi susceptible to the bulging factor.

In 1953 one of us (Rombouts, 1953) described how a rather weak antifungal antibiotic, produced by a Streptomyces strain isolated from soil in Holland, caused the hyphae of several fungi to swell in such a typical way that it can easily be distinguished by shape and size from all abnormal giant mycelial cells reported by other investigators (Wehmer, 1913; Elliot, 1917; Porter, 1924; Armitage \& Verdcourt, 1947; Verdcourt, 1950, 1952; Stevenson, 1954). The product responsible for this specific deformation was named the 'bulging factor'. The paper presented here deals with the chemical nature and mode of action of this factor.

\section{ME'THODS}

Cultural characteristics of the Streptomyces strain (our isolate no. S 303)

Aerial mycelium: usually abundant, white, later turning mouse grey. Sporophores produced in loose, open spirals.

Growth on defined medium agar: thin, folded, olive. Aerial mycelium scant, in fairy rings.

Growth on nutrient (glucose, Marmite, peptone) agar: thick, strongly folded. Aerial mycelium abundant. Agar turning dark brown.

Growth on starch agar: vegetative growth and aerial mycelium as on nutrient agar, but developing much slower. Hydrolysis poor. Pigment formation poor, if any.

Growth on potato glucose agar: thin, slightly folded, aerial mycelium abundant. No formation of soluble pigment.

Growth on glucose gelatine: Scant, no aerial mycelium. Liquefaction rapid around colonies. Formation of a yellow soluble pigment.

Growth on milk: dark brown ring on surface and formation of dark brown soluble pigment. Peptonization very slow.

Nitrate reduction: negative.

Temperature: optimum $26^{\circ}$, maximum $85^{\circ}$. 


\section{Production and assay of 'bulging factor'}

For the production of the antibiotic Streptomyces S 303 was grown submerged in a $20 \mathrm{l}$. aerated fermentation vessel at $25^{\circ}$ on a defined medium of the following composition: $\mathrm{KH}_{2} \mathrm{PO}_{4} 2 \mathrm{~g}$.; $\mathrm{Na}_{2} \mathrm{HPO}_{4} 4 \mathrm{~g}$.; $\mathrm{NH}_{4} \mathrm{Cl} 5 \mathrm{~g}$.; $\mathrm{MgSO}_{4} .7 \mathrm{H}_{2} \mathrm{O} 1 \mathrm{~g}$.; $\mathrm{FeSO}_{4} .7 \mathrm{H}_{2} \mathrm{O} 20 \mathrm{mg}$.; $\mathrm{ZnSO}_{4} .7 \mathrm{H}_{2} \mathrm{O} 10 \mathrm{mg}$; $\mathrm{CaCO}_{3} 3 \cdot 5$ g.; water $1000 \mathrm{ml}$.; pH 6.8 (cf. Charney, Roberts \& Fisher, 1952). The fermentation vessel was inoculated with the mycelium obtained by growing the streptomyces in shaken flasks at $25^{\circ}$ for two days in a nutrient medium composed of: soybean meal $10 \mathrm{~g}$.; liver hydrolysate $5 \mathrm{~g}$.; potato starch $10 \mathrm{~g}$.; $\mathrm{KH}_{2} \mathrm{PO}_{4} 1 \mathrm{~g}$.; $\mathrm{NaCl} 5 \mathrm{~g}$; $\mathrm{CoCl}_{2} 5 \mathrm{mg}$.; water $1000 \mathrm{ml}$.; pH 6.8. The shaken flasks, in their turn, were inoculated with spores collected from agar slopes.

Bulging factor was isolated from the culture fluid when the streptomyces had grown in it for one week. The $\mathrm{pH}$ value was then usually 7.0. Assays of bulging factor activity were accomplished by means of the following agar plate method.

Petri dishes were provided with a $4.5 \mathrm{~mm}$. thick layer of $2 \%(\mathrm{w} / \mathrm{v})$ Difco agar in distilled water. After solidification the surface was evenly seeded with washed pycnospores of Mycosphaerella pinodes (Berk. et Blox.) Stone. These two-celled spores were produced by the Ascochyta form of the fungus growing on a nutrient agar (sucrose 50 g.; $\mathrm{KNO}_{3} 1 \mathrm{~g}$.; $\mathrm{KH}_{2} \mathrm{PO}_{4} 0.5 \mathrm{~g}$.; $\mathrm{MgSO}_{4} .7 \mathrm{H}_{2} \mathrm{O}$ 0.5 g.; yeast extract 0.2 g.; agar 20 g.; water 1000 ml.; pH 6.5).

The germinating pycnospores were found to be most sensitive to bulging factor in the pink-coloured stage. They were collected from 4- or 5-day cultures and then washed twice with distilled water.

In the agar plates seeded with $M y$ cosphaerella pinodes holes $(0.5 \mathrm{~cm}$. diam.) were made by a corkborer and filled with 2 drops of bulging factor solution and 2 drops of distilled water or solution of a substance which we wished to investigate for its influence on the bulging activity (see 'Mode of action'). In a separate hole near the periphery of the plate 2 drops of a $10^{-2} \mathrm{M}-\mathrm{KCN}$ solution were pipetted to increase the sensitiveness of the test (see 'Mode of action').

A linear relation was found between the diameter of the zone showing bulging and the logarithm of bulging factor concentration. The same type of straight-line relation has been reported for other antibiotics, as well as for growth substances (Haenel, 1954; see Cooper, 1955, for a theoretical discussion). The activity of the culture fluid was usually about $20 \mathrm{~mm}$. (distance from the hole).

\section{Extraction of bulging factor from culture filtrates}

The culture fluid was adjusted to $\mathrm{pH} 1.5$ with $\mathrm{HCl}$. After $10 \mathrm{~min} .60 \mathrm{~g}$. charcoal (Norit P.K. 0.1-0.25 mm.) were added to 14. l. culture fluid. This suspension was stirred for $\mathbf{3 0} \mathrm{min}$. and then filtered. The pale yellow filtrate was readjusted to $\mathrm{pH} 7$ with $\mathrm{NaOH}$ and the resulting white precipitate removed by using a filter aid (Hyflosupercel). These manipulations resulted in a partial loss of activity. The remaining active factor was adsorbed onto $150 \mathrm{~g}$. Norit with continuous stirring for $30 \mathrm{~min}$. The charcoal was filtered off and 
washed successively with: distilled water, a $1 \%(w / v)$ solution of the disodium salt of ethylenediamine tetra-acetic acid ( $\mathrm{pH} 7 \cdot 5)$, twice with distilled water, and finally with $96 \%(\mathrm{v} / \mathrm{v})$ ethanol in water. Subsequently the bulging factor was eluted from the charcoal by stirring with $0 \cdot 1 \mathrm{~N}-\mathrm{HCl}$ in either methanol or $75 \%(v / v)$ acetone in water.

An active hygroscopic precipitate was obtained by adding dry ether to the pale yellow methanolic eluate. When $75 \%(\mathrm{v} / \mathrm{v})$ acetone in water was used for the elution the eluate was neutralized with Amberlite I.R.A. $400(\mathrm{OH})$ and then concentrated in vacuo. First an inactive fraction precipitated in the acetone-water solution. From the remaining concentrated solution the bulging factor was precipitated as a reineckate by adding a freshly prepared saturated solution of Reinecke salt. It was also possible to precipitate the bulging factor as an impure picrate.

\section{RESULTS}

\section{Chemical properties}

The bulging factor is very soluble in water, and not in any of the organic solvents tried. It is a basic substance. Experiments with the ion-exchanger Amberlite I.R.A. $400(\mathrm{OH})$ indicated that acidic groups are absent. It is quite stable at $\mathrm{pH}<7$ but unstable at $\mathrm{pH}>7$. An aqueous solution of the factor kept nearly its full activity at $\mathrm{pH} 2$ and $37^{\circ}$ for 6 days. At $\mathrm{pH} 11$, however, it soon lost activity. It is also rapidly destroyed at $\mathrm{pH} 2$ at $100^{\circ}$. In neutral solutions at $20^{\circ}$ with $1 \%$ maltase or $1 \%$ emulsin (both commercial preparations) for $16 \mathrm{hr}$. the activity remained constant. From the chemical properties we may conclude that the bulging factor has a streptothricin-like character (Peck et al. 1946; Bohonos et al. 1947; Charney et al. 1952; Carter, et al. 1954; Lindner \& Wallhäuser, 1955).

\section{Effect of the bulging factor on other micro-organisms}

The bulging factor has no visible effect on the growth and multiplication of Bacillus subtilis, Escherichia coli, Staphylococcus aureus, Mycobacterium phlei, M. tuberculosis, Brucella abortus, Salmonella typhimurium, Haemophilus pertussis, influenza virus, or chicken pox virus.

\section{Mode of action}

The action of certain chemicals (some of which are well known for the role they play in biochemical processes), on the width of the zone of bulging was investigated. In these experiments no $\mathrm{KCN}$ was added to the agar plates. Throughout these experiments a standard solution of bulging factor was used. In the holes 2 drops of this standard were mixed with 2 drops of a solution of the other chemical.

\section{Substances with no effect on activity}

No distinct effect on the diameter of the bulging zone was seen with the following substances: inorganic salts $\left(10^{-5}\right.$ to $\left.10^{-2} \mathrm{M}\right), \mathrm{NaCl}, \mathrm{NaF}, \mathrm{NaNO}_{3}$, $\mathrm{NaN}_{3}, \mathrm{NaHSO}_{3}, \mathrm{Na}_{2} \mathrm{~B}_{4} \mathrm{O}_{7}, \mathrm{KCl}, \mathrm{MgSO}_{4}, \mathrm{MnSO}_{4}, \mathrm{ZnSO}_{4}, \mathrm{CaCl}_{2} ;$ vitamins $\left(10^{-3}\right.$ to $\left.10^{-2} \% \mathrm{w} / \mathrm{v}\right)$, thiamine, riboflavin, pyridoxine, nicotinamide, panto- 
thenic acid; narcotics, chloroform and benzene $\left(10^{-4}\right.$ to $\left.10^{-1} \mathrm{M}\right)$, methanol, ethanol, and $n$-butanol ( 5 and $10 \% \mathrm{w} / \mathrm{v}$ ), urethane $\left(10^{-4}\right.$ to $10^{-1} \mathrm{M}$ ), dinitrophenol and malonic acid $\left(10^{-4}\right.$ to $\left.10^{-1} \mathrm{M}\right)$; aromatic acids, caffeic and chelidonic acid (saturated solutions), chlorogenic, protocatechuic, quinic, and shikimic acid $(1 \% \mathrm{w} / \mathrm{v})$; antibiotics $(0 \cdot 1 \% \mathrm{w} / \mathrm{v})$, streptomycin, benzylpenicillin, terramycin (oxytetracycline); plant growth substances, indolylacetic and indolylbutyric acids $\left(10^{-4}\right.$ and $\left.10^{-3} \mathrm{M}\right)$ naphthylacetic acid $\left(10^{-4}\right.$ and $\left.10^{-1} \mathrm{M}\right)$; natural substances, glucosamine. $\mathrm{HCl}\left(10^{-4}\right.$ to $\left.10^{-1} \mathrm{M}\right)$, camphor $\left(10^{-4}\right.$ to $\left.10^{-2} \mathrm{M}\right)$, quinine. $\mathrm{H}_{2} \mathrm{SO}_{4}\left(10^{-4} \mathrm{M}\right)$, coumarin $\left(10^{-4}\right.$ to $\left.10^{-2} \mathrm{M}\right)$, adenosinetriphosphate $\left(10^{-3}\right.$ to $\left.10^{-1} \% \mathrm{w} / \mathrm{v}\right)$, colchicine $\left(10^{-4}\right.$ to $\left.10^{-1} \% \mathrm{w} / \mathrm{v}\right)$; other substances, acetone $(5$ and $10 \% \mathrm{v} / \mathrm{v})$, the disodium salt of ethylenediaminotetraacetic acid $\left(10^{-3}\right.$ to $1 \mathrm{M}$ ), helianthine (saturated solution), Reinecke salt (saturated solution), picric acid $(10 \% \mathrm{w} / \mathrm{v})$, furan $(10 \% \mathrm{w} / \mathrm{v})$.

\section{Stimulation or inhibition of the activity}

Potassium cyanide. Addition of $\mathrm{KCN}$ in concentrations between $5 \times 10^{-5}$ and $5 \times 10^{-3} \mathrm{M}$ markedly increased the diameter of the bulging zone. Addition of $5 \times 10^{-2} \mathrm{M}-\mathrm{KCN}$ caused around the hole a $10 \mathrm{~mm}$.-wide zone in which neither growth of the fungus nor bulging activity was observed. Outside this toxic zone the bulging activity extended farther than in controls without KCN (e.g. to 25 and $19 \mathrm{~mm}$. from the hole, respectively). KCN dosed in separate holes had the same effect; this was obviously the result of the evaporation of the formed HCN. As a result of these observations we decided to add KCN to our assay plates in order to increase the sensitivity of the tests.

Potassium tri-iodide $10^{-3}$ to $10^{-1} \%(\mathrm{w} / \mathrm{v})$ activated the bulging factor (e.g. control $19 \mathrm{~mm}$.; with $10^{-2} \%$ (w/v) $\mathrm{KI}_{3}, 23 \mathrm{~mm}$.). $10 \%$ (w/v) $\mathrm{KI}_{3}$ caused a $15 \mathrm{~mm}$. wide toxic zone with neither growth nor bulging. Beyond this zone an $8 \mathrm{~mm}$. wide zone of bulging activity was observed though bulging was distinctly less pronounced than normal. Whereas low concentrations of $\mathrm{KI}_{3}$ stimulated bulging activity and high concentrations inhibited both growth and the bulging activity, $\mathrm{KI}_{3}$, unlike $\mathrm{KCN}$, is apparently capable of exerting another special effect of unknown nature which interferes with the normal reaction of the fungus to bulging factor.

Bicarbonate ion at some concentrations suppressed bulging activity without inhibiting growth of the fungus. For instance, addition of $2 \%(w / v) \mathrm{NaHCO}_{3}$ or $2 \%(\mathrm{w} / \mathrm{v}) \mathrm{NH}_{4} \mathrm{HCO}_{3}$ resulted in toxic zones (no growth and no bulging) of $8 \mathrm{~mm}$; outside this zone there was no bulging though growth was normal, whereas controls gave bulging zones of $19 \mathrm{~mm}$.

\section{DISCUSSION}

The general picture of the abnormal development of fungal cells under the influence of the bulging factor has been described in an earlier paper by one of us (Rombouts, 1953). The typical swelling of the hypha starts always at the very tip, fully developed mycelial cells being resistant to the bulging factor. Since it is most likely that normal hyphal elongation takes place as a result of internal pressure on the young plastic cell wall at or just behind the hyphal 
tip, it was suggested that the bulging factor might act specifically upon the cell-wall material, or its biosynthesis, apparently by changing its directed plasticity.

However, in view of the earlier observation that in some Fungi imperfecti the bulging factor may exert its effect already on the germinating conidia before a proper germtube has emerged, combined with the new observations described in this paper, the following new hypothesis may be put forward. Water diffuses ('passively') into the growing young hyphae and germinating spores. The water in excess of the needs for growth is removed from the fungal cell by an energy-requiring mechanism ('actively'). Bulging factor interferes with the latter mechanism. Osmotic uptake of water is probably enhanced in primary hyphae during germination of the spores, when large molecules are broken down into smaller ones, which would increase the osmotic pressure of fungus cell-content. An exogenous source of inorganic nutrients and of a respirable carbon compound appears to be unnecessary for spore germination and the initial growth. This points to the fact that initial needs for nutrients are covered by the spore content. The $\mathrm{KCN}$ effect suggests that a cyanidesensitive component of the aerobic respiration participates in the waterremoving mechanism, possibly via a cytochrome-oxidase system. Such an energy-requiring pumping mechanism has not yet been proved or postulated to exist in fungi. Contractile vacuoles which serve the same purpose are a common feature among unicellular organisms. These have also been observed in phanerogams where they seem to play a role in sudden movements but are apparently not necessary for the maintenance of normal water balance (Weintraub, 1951; Toriyama, 1953). An active water secretion has been demonstrated in cells of several tissues of higher animals (Robinson, 1950; Wilson, 1954). These cells swell in isomotic salt solutions when they are deprived of their oxygen supply or when they are poisoned with enzyme inhibitors. The opposite, an active uptake of water, has been found in cells of certain tissues of higher plants (Reinders, 1942; Bogen, 1954).

We do not know how to explain the influence of $\mathbf{H C O}_{3}$-ion on the bulging effect. It is unlikely that such ions are capable of a chemical decomposition of the bulging factor. The system by which the bulging factor exerts its specific action is apparently very sensitive to $\mathrm{HCO}_{3}$-ion. It should be remembered that $\mathrm{CO}_{2}$ is an important component in many carboxylation reactions of the living cell. In this connexion we think of the inhibitory effect of high $\mathrm{CO}_{2}$ concentrations on the oxaloacetic acid decarboxylase in the fungus Rhizopus nigricans (Foster \& Davis, 1949), of the possible role of $\mathrm{CO}_{2}$ in piling up of intermediates between $\alpha$-ketoglutarate and citrate (Cantino, 1951), and of the inhibition by $\mathrm{HCO}_{3}$-ion of the respiration of excised roots (Miller \& Thorne, 1956).

In the present state of knowledge it is not possible to choose between the previous and this new explanation of the bulging factor effect.

We are indebted to Dr E. H. Reerink for his stimulating interest and to Dr C. A. de Bock for testing the effect on bacteria and viruses. Our thanks are also due to Dr J. Visser who advised in the use of the fermenters, and to Mrs H. H. Hellekamp for much technical assistance. 


\section{REFERENCES}

Armitage, F. D. \& Verdcourt, B. (1947). The effect of sodium pentachlorphenate on the morphology of Aspergillus niger. Research, 1, 236.

Bogen, H. J. (1954). Nichtosmotische Stoffaufnahme. Z. Bot. 42, 151.

Bohonos, N., Emerson, R. L., Whiffen, A. J., Nash, M. P. \& De Boer, C. (1947). A new antibiotic produced by a strain of Streptomyces lavendulae. Arch. Biochem. 15, 215.

Cantino, E. C. (1951). Metabolism and morphogenesis in a new Blastocladiella. Leeurwenhoek ned Tijdschr. 17, 325.

Carter, H. E., Clark, R. K., Kohn, P., Rothrock, J. W., Taylor, W. R., West, C. A., Whitfield, G. B. \& Kackson, W. G. (1854). Streptothricin I. Preparation, properties and hydrolysis products. J. Amer. chem. Soc. 76, 566.

Charney, J., Roberts, W. S. \& Fisher, W. P. (1952). Pleocidin, a new antibiotic related to streptothricin. Antibiot. \& Chemother. 2, 307.

Cooper, K. E. (1955). Theory of antibiotic inhibition zones in agar media. Nature, Lond. 176, 510.

Elliot, J. A. (1917). Taxonomic characters of the genera Alternaria and Macrosporium. Amer. J. Bot. 4, 439.

Foster, J. W. \& Davis, J. B. (1949). Carbon dioxide inhibition of anaerobic fumarate formation in the mold Rhizopus nigricans. Arch. Biochem. 21, 135.

HaEnel, H. (1954). Keimringbildung bei Neurospora-mutanten. Naturwissenschaften, 41, 362.

Linder, F. \& Wallhäuser, K. H. (1955). Die Arbeitsmethoden der Forschung zur Auffindung neuer Antibiotika. Arch. Mikrobiol. 22, 219.

Mrller, G. W. \& THORNe, D. W. (1956). Effect of bicarbonate ion on the respiration of excised roots. Plant Physiol. 31, 151.

Peck, R. L., Walti, A., Graber, R. P., Flynn, E., Hoffhine, Jr., C. E., Allfrey, V. \& FolKers, K. (1946). Streptomyces antibiotics. VI. Isolation of streptothricin. J. Amer. chem. Soc. 68, 772.

Porter, C. L. (1924). Concerning the characters of certain fungi as exhibited by their growth in the presence of other fungi. Amer. J. Bot. $11,168$.

ReINDERs, D. E. (1942). Intake of water by parenchymatic tissue. Rec. trav. bot. néerl. 39, 1.

Robinson, J. R. (1950). Osmoregulation in surviving slices from the kidneys of adult rats. Proc. Roy. Soc. B, 137, 378.

Roмвоuтs, J. E. (1953). Abnormal development of fungi induced by antibiotics. Atti VI Congr. int. Microbiol. 3, 205.

Stevenson, I. L. (1954). Antibiotic production by Actinomycetes in soil demonstrated by morphological changes induced in Helminthosporium sativum. Nature, Lond. 174, 598.

Toriyama, H. (1953). Observational and experimental studies of sensitive plants. I. The structure of parenchymatous cells of pulvinus. Cytologia, 18, 284.

Verdcourt, B. (1950). The swelling of mould spores in the presence of hydroxy compounds. Trans. Brit. mycol. Soc. 33, 323.

VERDCOURT, B. (1952). The effect of certain phenolic compounds on the germination and growth of microfungi. Mycologia, 44, 377.

WeHMER, C. (1913). Übergang älterer Vegetationen von Aspergillus fumigatus in 'Riesenzellen' unter Wirkung angehäufter Säure. Ber. deutsch. bot. Ges. 31, 257.

Weintraub, M. (1951). Leaf movements in Mimosa pudica L. New Phytol. 50, 357.

Wilson, T. H. (1954). Ionic permeability and osmotic swelling of cells. Science, 120, 104. 